\title{
Effect of three types of liquid compost combined with Avicennia marina leaves on growth and survival of tiger prawns (Penaeus monodon)
}

\author{
Restiana Wisnu Ariyati - Sri Rejeki • Lestari L. Widowati • \\ Tita Elfitasari $\cdot$ Roel H. Bosma
}

Received: 27 February 2019/Accepted: 26 August 2019/Published online: 10 September 2019

(C) The Author(s) 2019

\begin{abstract}
The sustainability of prawn farming in brackish water ponds is controversial because of low yields and a history of mangrove clearing. Low yields are due largely to insufficient preparation of pond bottoms. Mangrove trees are often planted on pond bunds as window dressing. This study examines the effect of three types of liquid compost from vegetable, fruit, and both vegetable and fruit in tanks to which whole or chopped Avicennia marina leaves have been added to mimic local pond conditions. In a split-plot design, 28 square tanks were each stocked with one hundred 15-day-old post-larvae tiger prawns (Penaeus monodon). Four tanks were used as controls and 24 were assigned to the treatments, 12 with whole and 12 with chopped leaves. Of the treatment tanks, 4 received liquid compost from vegetable, 4 received fruit, and 4 received mixed vegetable and fruit. Shrimp were weighed at the start, halfway point, and the end of the 50-day trial, and fed at $5 \%$ of the estimated total weight; survival was counted at the end. The survival rates of treatments and controls $(65-76 \%)$ were not significantly different. Shrimp in water with vegetable compost grew significantly faster $\left(2.7 \%\right.$ day $\left.^{-1}\right)$ than in both treatments with fruit $\left(2.5 \%\right.$ day $\left.^{-1}\right)$, while all treatments were associated with significantly faster growth than were the controls $\left(2.0 \% \mathrm{day}^{-1}\right)$. The lower growth rate of shrimp fed fruit compost may have been due to dinoflagellates, which are known to negatively affect shrimp. Shrimp in tanks with chopped mangrove leaves grew slightly better than shrimp in tanks with whole mangrove leaves.
\end{abstract}

Keywords LEISA $\cdot$ Aquaculture $\cdot$ Shrimp $\cdot$ Mangrove $\cdot$ Fertilizer

\section{Introduction}

Traditional prawn farmers in Indonesia minimize external inputs, such as feed, but most do not practice responsible aquaculture practices, such as regular curing of the pond bottom. Most also rely on a single sluice gate to allow brackish water to flow into the pond and trap seafood. These practices, coupled with a lack of technical training and inadequate expert advice, have resulted in low and volatile harvests and correspondingly low incomes. The situation applies more to shrimp farmers than to milkfish farmers.

To increase knowledge, and ultimately, yields and income, coastal field schools managed by the Building with Nature project taught and trained the farmers during one cropping cycle about responsible fish farming

R. W. Ariyati $(\varangle) \cdot$ S. Rejeki · L. L. Widowati · T. Elfitasari

Aquaculture Department, Faculty of Fisheries and Marine Sciences, Diponegoro University, Semarang, Indonesia

e-mail: resti_wisnoe@yahoo.com

R. H. Bosma

Aquaculture and Fisheries Group, Wageningen University, Wageningen, The Netherlands 
and the low external input for sustainable aquaculture (LEISA) approach, which was first used in agriculture (Reijntjes et al. 1992). LEISA optimizes existing local resources by combining various components, maximizes recycling, and reduces environmental damage by minimizing external inputs, and maintains sustainable and adequate production in the long term. LEISA was introduced successfully to milkfish farmers through coastal field schools in Sulawesi by Brown and Fadillah (2013), and recently to shrimp farmers in Demak regency of Central Java through Building with Nature. To make liquid compost, shrimp and milkfish farmers learn to ferment vegetable and fruit wastes from households and markets. They then use this liquid compost to cure the bottom of the pond and maintain the pond's water quality during the culture period. The different effects of using fruit or vegetable are unknown, but the microbial community that develops during anaerobic or aerobic composting processes depends in part on the type and relative amount of input materials (FrankeWhittle et al. 2014).

As residues of both vegetable and fruit are limited and feed is expensive, but mangrove leaves are abundant, we tested the effect of adding Avicennia marina (Forssk, Vierh.) leaves to the water. The Indonesian government's program to maintain mangroves requires that farmers plant mangrove trees on pond bunds in the form of silvo-aquaculture (Primavera 2000). Avicennia marina is a medium-sized pioneer species with pneumatophore roots (Chanda et al. 2016) and is highly tolerant to elevated salinity and sedimentation. Its leaves, which range in length from 4 to $11 \mathrm{~cm}$, have a thinner leaf cuticle, higher initial nitrogen concentration, lower $\mathrm{C}: \mathrm{N}$ ratio, lower tannin levels, and faster decomposition rates than other species (Robertson 1988; Camilleri 1989; Steinke et al. 1990; Primavera 1993). Moreover, A. marina leaves appear to regulate the $\mathrm{pH}$ of shrimp ponds and can serve as a potential pond fertilizer (Primavera 2000). In coastal Java, farmers use A. marina leaves and seeds as fodder and food, and they value the species for its medicinal properties. Ikhwanuddin et al. (2014) found that the leachate of Terminalia catappa (a mangrove-associated species) gave higher growth rates of post-larva Penaeus monodon than whole-leaf litter, and Rejeki et al. (2019) confirmed this for leachate and chopped leaves of Rhizophora apiculata and A. marina. R. apiculata was found to have negative effects (Chanda et al. 2016; Primavera 1993), although it is the most planted species in Indonesian silvo-aquaculture.

This study compared the effects of liquid composts of vegetable, fruit, or a mixture of both, and examined the effects of adding whole or chopped leaves of A. marina on the growth and survival of $P$. monodon juveniles. The microorganisms present in the liquid compost were expected to accelerate the decomposition process of A. marina leaves. The use of whole and chopped leaves assumes that the chopped leaves will decompose faster and their nutrients will be used by fungi and bacteria, which will in turn be used by nitrogenrich detritus that can be eaten by the shrimp.

\section{Materials and methods}

Research design

A multifactorial split-plot design with two factors in the main plots and three factors in the subplots was used. The main factor (A) had 2 treatments: A1, whole A. marina mangrove leaves; and A2, chopped A. marina mangrove leaves, both dosed at $100 \mathrm{~g} / \mathrm{tank}$, or $0.125 \mathrm{~g} \mathrm{~L}^{-1}$.

Avicennia marina leaves were collected from mangrove plants around the research location and then placed in litter bags constructed from nylon nets of 3-mm mesh size to dry in the shade at room temperature for 3 days before adding them to the experimental tanks.

The subplot factor, liquid compost (B), consisted of 3 treatments: B1, fermented vegetable waste $(10 \mathrm{~kg}$ of mixed cabbage, greens, mustard, kale, and carrots); B2, fermented fruit waste (10 kg of mixed papaya, dragon fruit, and melon); and $\mathrm{B} 3$, fermented mixed vegetable $(5 \mathrm{~kg})$ and fruit $(5 \mathrm{~kg})$ waste.

The substrates for B3 came from the same sources as B1 and B2, and the ratios between the individual substrates were equal. The selection of substrates for the liquid compost was based on local availability at zero cost; the farmers could collect them as market or household waste. The fermentation process lasted for 10 days in a closed barrel to which the following ingredients were submerged in water: $10 \mathrm{~kg}$ of chopped substrate, $1 \mathrm{~L}$ of molasses, 4 granules (approximately $5 \mathrm{~g}$ ) of yeast used to ferment cassava, and $1 \mathrm{~kg}$ of rice 
bran. The treatments were A1B1, A1B2, A1B3, A2B1, A2B2, and A2B3, each with four replicates, for 50 days. The control tanks received commercial feed only, without liquid compost or mangrove leaves.

Square plastic tarpaulins tanks with bamboo frames were set in a semi-indoor hangar covered with transparent fiberglass roofing. Twenty-eight experimental tanks were stocked with one hundred 15-day-old, post-larva P. monodon obtained from the Brackish Water Research and Development Centre in Jepara. Each tank contained $800 \mathrm{~L}$ of brackish water (salinity $21 \mathrm{~g} \mathrm{~L}^{-1}$ ) and a substrate layer ( $\left.\mathrm{pH} 6.5\right)$ of $\pm 5 \mathrm{~cm}$ clayeyloam soil from the bottom of a pond near the station. Providing a substrate layer on the bottom of each tank mimics the environmental conditions that foster juvenile shrimp growth in brackish ponds. The water was aerated continuously and water from the same source was added when needed to keep volumes at original levels. A week before the experiment started, $20 \mathrm{~mL}$ of liquid compost and dried leaves were added according to the treatments. Every week, during the research period, $5 \mathrm{~mL}$ of liquid compost was added to the respective treatments by diluting $5 \mathrm{~mL}$ in $500 \mathrm{~mL}$ of brackish water and distributing this evenly over the eight tanks.

The post-larva shrimp were fed with commercial pellets at $5 \%$ of total body weight, estimated at the start and the halfway period. To encourage shrimp to use the natural feed provided and produced in the tanks, this feeding rate was two-thirds of the optimal rate for monodon juveniles (Niu et al. 2016). Pellets containing $41 \%$ protein, $5 \%$ fat, $2 \%$ fiber, $13 \%$ ash, and $11 \%$ moisture were added twice a day.

Data collection and calculation

\section{Growth performance and survival rate}

Weights were measured three times to calculate growth and adjust feeding. The initial body weight was determined for the whole population (3000 post-larva shrimp) by randomly sampling 350 individuals in groups of 10 to minimize fluctuations due to wind. Halfway through the experimental period, 25 shrimp from each tank were weighed. The final body weights were determined by weighing all surviving individuals and dividing them by the total number of individuals. The total shrimp biomass of the tanks was expressed per tank of $1 \mathrm{~m}^{2}$. Weighing was carried out by using an A\&D HL-100 electronic scale with an accuracy of $0.01 \mathrm{~g}$.

The specific growth rate (SGR, in \% day ${ }^{-1}$ ) was calculated using Busacker et al.'s (1990) formula:

$$
\mathrm{SGR}=\frac{\ln \mathrm{BW}_{\mathrm{t}}-\ln \mathrm{BW}_{\mathrm{o}}}{t} \times 100 \%,
$$

where $\mathrm{BW}_{\mathrm{t}}$ is the final body weight $(\mathrm{g}) ; \mathrm{BW}_{\mathrm{o}}$ is the initial body weight $(\mathrm{g})$; and $t$ is the duration of the experiment (days).

To calculate the survival rate (SR), we counted the surviving numbers per tank, and applied Busacker et al.'s (1990) formula:

$$
\mathrm{SR}=\frac{N_{\mathrm{t}}}{N_{\mathrm{o}}} \times 100 \%
$$

where $N_{\mathrm{t}}$ is the number of prawns collected at sampling time $t$ and $N_{\mathrm{o}}$ is the number of prawns initially stocked.

\section{Water quality parameters}

Ammonia, nitrate, and phosphate values in the water were measured twice weekly at the Diponegoro University (UNDIP) Environmental Engineering Laboratory. A 500-mL water sample was aggregated in situ, to which concentrated $\mathrm{H}_{2} \mathrm{SO}_{4}$ was added to decrease the $\mathrm{pH}$ to 2 . The sample was then transported in an insulated box. The ammonium salicylate method was used for ammonia analysis, nitrate diazotization for nitrate analysis, and the phosphate ascorbic acid method for phosphate analysis, followed by spectrophotometer measurements at various wavelengths. Temperature, $\mathrm{pH}$, salinity, and dissolved oxygen (DO) were measured in situ using a water quality checker. 
Plankton abundance was measured ex situ by filtering water with a $25-\mu \mathrm{m}$ mesh plankton net, then storing it in a $350-\mathrm{mL}$ sample bottle with a $4 \%$ formalin solution. The sample was transported to the Marine Science Laboratory FPIK at UNDIP in an insulated box. The water samples taken for plankton abundance measurements were analyzed at the beginning, middle, and end of the study.

The type and total amount of bacteria in the liquid compost were counted in a sample taken just before the application. A 500-mL sample was transported in an insulated box with ice to laboratory. The bacteria were counted as the total plate count, based on the USDA (2015) procedure. The bacteria were identified after being cultured on an agar plate by the spread-plate method (Cowan 2003).

Data analysis

Data generated in this study were analyzed using SigmaPlot ${ }^{\circledR} 12$ software to calculate the means and standard deviations. The normality of the data was checked using the Shapiro-Wilk test. The growth and SR data were analyzed using a two-way split-plot analysis of variance (ANOVA). In the latter analysis, we used the data of the control twice, that is, as part of both plots of the mangrove treatment, because the number of available tanks was limited. In cases of significant interactions and impacts of factor B, we analyzed the data further with multiple-comparison post hoc Dunn and Tukey tests.

A plankton diversity index was calculated using the Shannon and Wiener equation and a domination index by the Margalef equation. The results are presented descriptively.

\section{Results}

The effects of replication and interaction between the factors were not significant in the multifactorial splitplot ANOVA of the SR (Table 1) or of the SGR (Tables 2 and 3). We, therefore, used the ANOVA results for the main factors.

Survival rates of monodon juveniles

The average SRs varied between 65 and 76\% (Fig. 1). The highest SRs were reached with a liquid compost of either vegetable or fruit; the SR for the mixed compost was about the same as that for the control. However, neither the treatment of mangrove leaves nor that of liquid compost had a significant effect on the SRs (Table 1).

Specific growth rate and biomass of post-larvae monodon shrimp

The liquid compost significantly $(p<0.001)$ improved the growth of shrimp compared with the controls; chopping the leaves of $A$. marina had a significant effect $(p<0.01)$ within the treatments of the compost (Table 2). The SGR of the chopped mangrove leaves was about $0.4 \%$ points higher than that of the treatments with the whole leaves (Fig. 2). Adding compost improved the SGR by between 0.2 and $1.2 \%$ points day $^{-1}$ compared with the control. Due to the cumulated effects of chopped mangrove leaves and liquid compost made with vegetable, the SGR of monodon shrimp reached $2.7 \% \pm 0.2 \%$ day $^{-1}$, while that in the compost

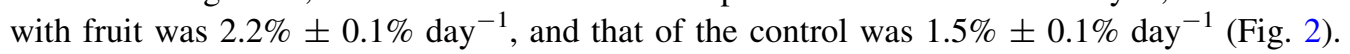

Table 1 Multifactorial split-plot ANOVA on the effects of mangrove leaves and compost type on P. monodon SR

\begin{tabular}{lllll}
\hline Source of variation & $d f$ & MS & $F$ & Sig. \\
\hline Intercept & 1 & 125.778 & 7.843 & 0.08 \\
Mangrove type & 1 & 9.4 & 0.89 & 0.79 \\
Repetition & 4 & 32.994 & 0.61 & 0.62 \\
Liquid compost type & 2 & 211 & 1.75 & 0.22 \\
Mangrove * compost & 2 & 0.9 & 0.007 & 0.99 \\
\hline
\end{tabular}


Table 2 Multifactorial split-plot ANOVA on the effects of mangrove leaves and compost type on P. monodon SGR

\begin{tabular}{lcccc}
\hline Source of variation & $d f$ & MS & $F$ & Sig. \\
\hline Intercept & 1 & 84.8 & 16.737 & $\mathbf{0 . 0 0}$ \\
Mangrove type & 1 & 1.04 & 28.8 & $\mathbf{0 . 0 1}$ \\
Repetition & 4 & 0.01 & 0.16 & 0.95 \\
Compost type & 12 & 0.73 & 32.5 & $\mathbf{0 . 0 0}$ \\
Mangrove * compost & 12 & 0.01 & 0.20 & 0.82 \\
\hline
\end{tabular}

Bold values indicate significant differences

Table 3 Range of water quality parameters and the recommended range for tiger prawn (in $\mathrm{mg} / \mathrm{L}$, unless mentioned)

\begin{tabular}{lccccccc}
\hline Water quality parameters & \multicolumn{2}{l}{ Treatments } & & & \multirow{2}{*}{ Recom-mended range* } \\
\cline { 2 - 6 } & A1B1 & A1B2 & A1B3 & A2B1 & A2B2 & A2B3 & \\
\hline DO & $5.5-6.4$ & $5.7-6.4$ & $5.2-6.3$ & $5.2-6.3$ & $5.1-6.3$ & $5.4-6.5$ & $>3$ \\
Salinity $\left(\mathrm{g} \mathrm{L}^{-1}\right)$ & $30-31$ & $30-31$ & $30-31$ & $30-31$ & $30-31$ & $30-31$ & $5-40$ \\
pH & $8.3-8.5$ & $8.3-8.5$ & $8.3-8.5$ & $8.3-8.5$ & $8.3-8.5$ & $8.3-8.5$ & $7.5-8.5$ \\
Temp $\left({ }^{\circ} \mathrm{C}\right)$ & $27-28$ & $27-28$ & $27-28$ & $27-28$ & $27-28$ & $27-28$ & $28-32$ \\
Ammonia $\left(\mathrm{NH}_{3}\right)\left(\mathrm{mg} \mathrm{L}^{-1}\right)$ & $0.05-0.05$ & $0.05-0.08$ & $0.04-0.06$ & $0.05-0.05$ & $0.05-0.07$ & $0.04-0.07$ & $\leq 0.01$
\end{tabular}

*Regulation of the Minister of Maritime Affairs and Fisheries of the Republic of Indonesia No. 75/Permen-KP/2016. General guidelines for Penaeus monodon and Litopenaeus vannamei

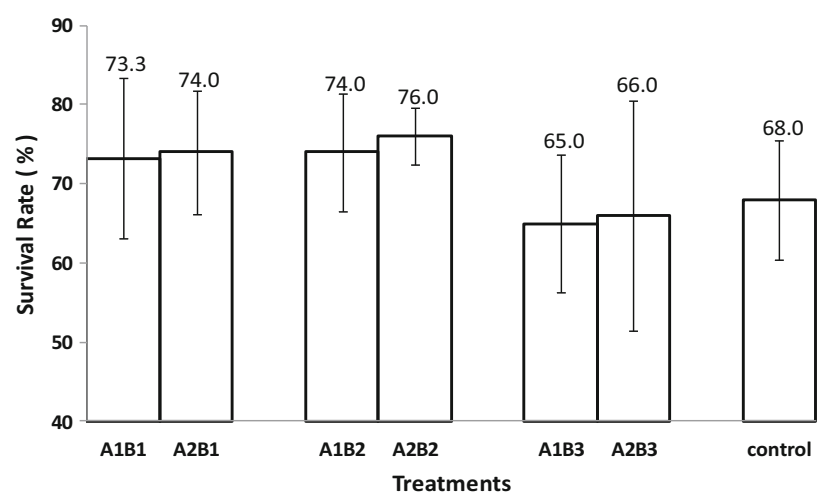

Fig. 1 Histogram of mean survival rates, with standard deviations, of tiger shrimp for each treatment

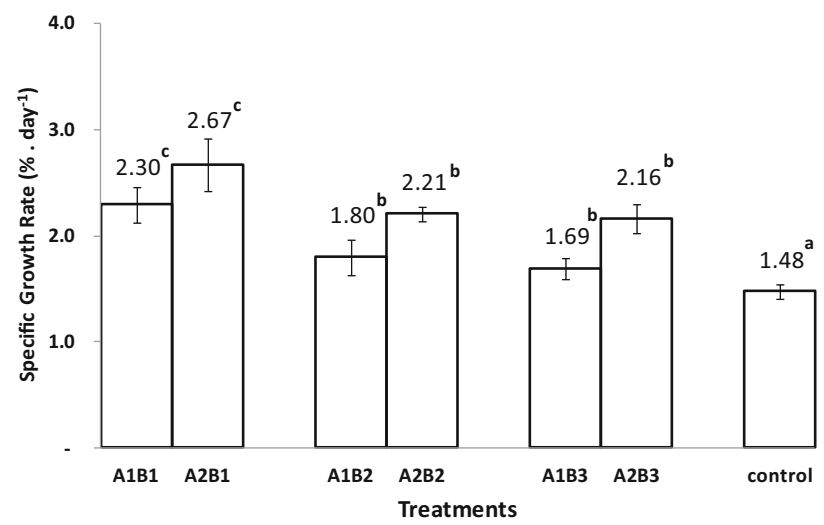

Fig. 2 Histogram of the mean specific growth rate of $P$. monodon, with standard deviations, for each treatment 
The liquid compost significantly $(p<0.001)$ improved the biomass of shrimp compared with the control; within the compost treatments, the chopped leaves of A. marina had a significant effect $(p<0.01)$ compared with the whole leaves. Per tank, the final biomass of shrimp was the highest, $275 \pm 72 \mathrm{~g}$, in the treatment of vegetable compost plus leaves; intermediate for the fruit compost with leaves, $181 \pm 18 \mathrm{~g}$; and the lowest for the control, $71 \pm 8.6 \mathrm{~g}$ (Fig. 3). The biomass of the tanks with chopped A. marina leaves was about $40 \%$ higher than that in the treatments with the whole leaves.

Water quality, liquid compost, plankton, and bacteria

During the study, the levels of DO, salinity, $\mathrm{pH}$, and temperature did not differ significantly by treatment (Table 3). Although the temperatures were at the lower limit and the $\mathrm{pH}$ was close to the upper limit, these chemical and physical water quality parameters, as well as DO, remained in the ranges recommended for shrimp cultivation. The ammonia levels were fairly high compared with the standard and fluctuated more, but were not significantly different between the treatments. The condition of the shrimp in all treatments was normal as the levels remained below toxic levels $(0.08 \mathrm{mg} / \mathrm{L})$.

The frequency of sampling was insufficient for a statistical comparison of the treatments' effects on nutrient change. However, the average concentrations of $\mathrm{PO}_{4}$ and $\mathrm{NO}_{3}$ in the tanks increased during the experiment from $0.07 \pm 0.0$ to $0.12 \pm 0.1 \mathrm{mg} \mathrm{L}^{-1}$ and from $0.05 \pm 0.02$ to $0.07 \pm 0.03 \mathrm{mg} \mathrm{L}^{-1}$, respectively (Fig. 4). Both parameters showed the same trend - a slight decrease in the first 2 weeks and a gradual increase in the following weeks. For $\mathrm{PO}_{4}$, the increase was the strongest for the mixed compost and intermediate for the vegetable compost, while no effect was seen with the fruit compost. For $\mathrm{NO}_{3}$, a relative increase was observed for the fruit compost only.

Liquid compost with vegetable contained the highest concentration of total nitrogen, $\mathrm{P}_{2} \mathrm{O}_{5}$, and $\mathrm{K}_{2} \mathrm{O}$ compared with that of the other treatments (Table 4). The low $\mathrm{P}_{2} \mathrm{O}_{5}$ content in the mixed compost contrasts with the high $\mathrm{PO}_{4}$ content in the tank water. As for the $\mathrm{N}$ content in the compost and the tank water, the treatments of fruit and of vegetable switched ranks.

All treatments had plankton from three genera: Bacillariophyceae, Dinophyceae, and Cyanophyceae (Table 5). The diversity was low for all three $\left(H^{\prime}<2.3\right)$, none of the species dominated $(D<0.5)$, and uniformity was high $\left(e^{\prime}>0.5\right)$. However, Thalassiotrix and Guinardia sp. were found only in the treatments of whole mangrove leaves, while Nitzschia sp. was found only in chopped mangrove leaf treatments. The presence of Ceratium sp. was typical for the vegetable compost. Treatments containing both vegetable and fruit tended to have the highest values for diversity, dominance, and uniformity.

The total bacterial count was the highest for the vegetable liquid compost, the lowest for the fruit compost, and intermediate for the vegetable-fruit mixture (Table 6). Bacillus cereus and Clostridium sp. were found in all three, while Streptococcus sp. and Bacillus thuringiensis were found only in the fruit compost. The latter two were not found in the mixed compost. Only four of the six species found in the fruit compost were also found in the mixed compost, while all bacteria found in the vegetable compost were found in the mixed liquid compost. The bacteria had either P-solubilizing, N-fixing, cellulose-degrading, fermentation, probiotic, or

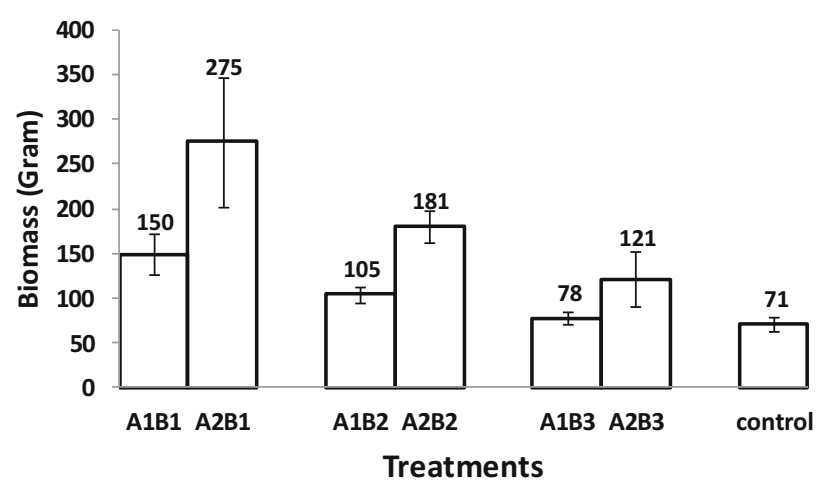

Fig. 3 Histogram of the biomass of P. monodon, with standard deviations, for each treatment 
Phosphate $\left(\mathrm{PO}_{4}\right)\left(\mathrm{mg}^{\mathrm{L}} \mathrm{L}^{-1}\right)$

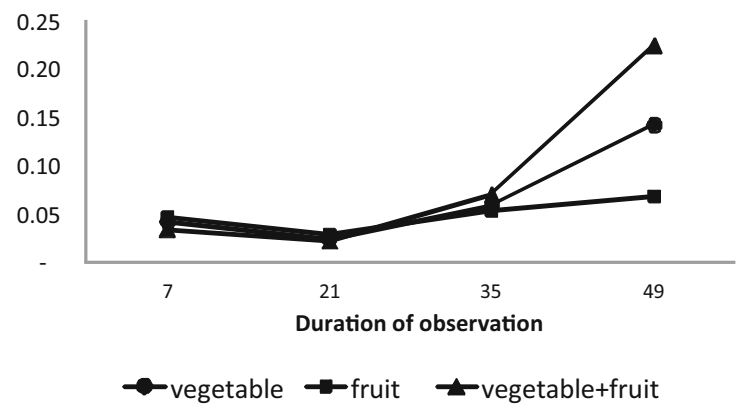

Nitrate $\left(\mathrm{NO}_{3}\right)\left(\mathrm{mg}^{\mathrm{L}} \mathrm{L}^{-1}\right)$

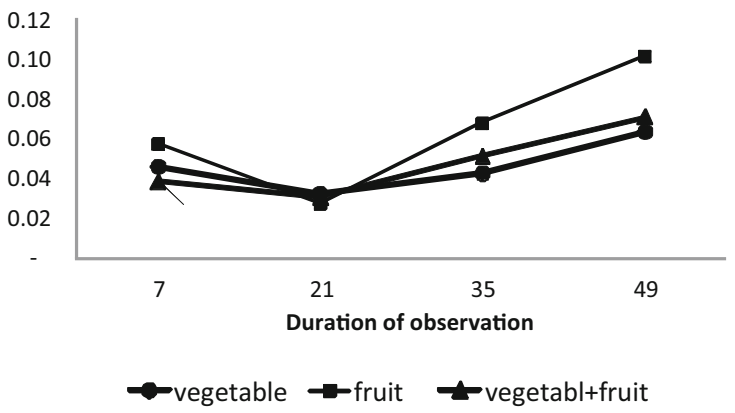

Fig. $4 \mathrm{PO}_{4}$ and $\mathrm{NO}_{3}$ contents in tank water for the three types of compost at four time points

Table 4 The content $\left(\mathrm{mg}^{-1} \mathrm{~L}\right)$ of $\mathrm{N}, \mathrm{P}$, and $\mathrm{K}$ in the three types of liquid compost

\begin{tabular}{llllr}
\hline Treatments & Liquid compost & Nitrogen total & $\mathrm{P}_{2} \mathrm{O}_{5}$ & $\mathrm{~K}_{2} \mathrm{O}$ \\
\hline A1 & Vegetable & 0.21 & 2.57 & 0.71 \\
A2 & Fruit & 0.16 & 1.96 & 0.55 \\
A3 & Vegetable and fruit & 0.15 & 0.72 & 0.51 \\
\hline
\end{tabular}

Table 5 Plankton species counts in the water of the six treatments and the indexes for plankton diversity, uniformity, and dominance

\begin{tabular}{|c|c|c|c|c|c|c|}
\hline Plankton & A1B1 & A1B2 & A1B3 & A2B1 & $\mathrm{A} 2 \mathrm{~B} 2$ & A2B3 \\
\hline Total count $\left(\mathrm{n} \mathrm{mL}^{-1}\right)$ & 7.498 & 8.941 & 12.688 & 8.651 & 9.517 & 11.823 \\
\hline \multicolumn{7}{|l|}{ Bacillariophyceae } \\
\hline Rhizosolenia sp. & 865 & 2.019 & 1.730 & 865 & 2.019 & 2.019 \\
\hline Pleurosygma sp. & 577 & 865 & 3.749 & 2.019 & 1.442 & 3.749 \\
\hline Synedra sp. & 2.019 & 2.019 & 2.019 & 1.442 & 1.730 & 2.307 \\
\hline Thalassiotrix sp. & 577 & 577 & - & - & - & - \\
\hline Coscinoduscus sp. & 1.153 & 1.442 & 1.153 & 1.442 & 1.442 & 865 \\
\hline Guinardia sp. & - & - & 1.442 & - & - & - \\
\hline Nitzschia sp. & - & - & - & 288 & 865 & 1.153 \\
\hline \multicolumn{7}{|l|}{ Dinophyceae } \\
\hline Ceratium sp. & 577 & - & - & 288 & - & - \\
\hline Peridinium sp. & - & - & 865 & 288 & - & 577 \\
\hline \multicolumn{7}{|l|}{ Cyanophyceae } \\
\hline Oscillatoria sp. & 1.730 & 2.019 & 1.730 & 2.019 & 2.019 & 1.153 \\
\hline Diversity index $H^{\prime}$ & 1.44 & 1.59 & 1.90 & 1.58 & 1.59 & 1.78 \\
\hline Uniformity index $e^{\prime}$ & 0.69 & 0.77 & 0.92 & 0.76 & 0.76 & 0.85 \\
\hline Domination index $D$ & 0.07 & 0.11 & 0.20 & 0.10 & 0.11 & 0.19 \\
\hline
\end{tabular}

Bold values indicate significant differences

antibiotic properties; but the P-solubilizing bacteria, Microbacterium sp., became dominant in the mix where B. thuringiensis from the fruit compost was not present.

\section{Discussion}

The present study shows that liquid compost and mangrove leaves significantly improved the SGR of $P$. monodon juveniles without affecting their SRs. Chopping the mangrove leaves further enhanced this SGR. 
Table 6 Total number and type of bacteria found in the liquid compost

\begin{tabular}{|c|c|c|c|}
\hline \multirow[t]{2}{*}{ Type of bacteria } & \multicolumn{3}{|c|}{ Source of liquid compost } \\
\hline & Vegetable & Fruit & Vegetable and fruit \\
\hline \multicolumn{4}{|l|}{ Phosphate-solubilizing bacteria } \\
\hline Bacillus cereus & $\sqrt{ }$ & $\sqrt{ }$ & $\sqrt{ }$ \\
\hline Bacillus thuringiensis & & $\sqrt{ }$ & \\
\hline Microbacterium sp. & $\sqrt{ }$ & & $\sqrt{ }$ \\
\hline \multicolumn{4}{|l|}{ Nitrogen-fixing bacteria } \\
\hline Clostridium sp. & $\sqrt{ }$ & $\sqrt{ }$ & $\sqrt{ }$ \\
\hline \multicolumn{4}{|l|}{ Cellulose-degrading bacteria } \\
\hline Cellulomonas sp. & $\sqrt{ }$ & & $\sqrt{ }$ \\
\hline \multicolumn{4}{|l|}{ Fermentation bacteria } \\
\hline Streptococcus sp. & & $\sqrt{ }$ & \\
\hline \multicolumn{4}{|l|}{ Probiotic bacteria } \\
\hline Enterococcus faecium & $\sqrt{ }$ & & $\sqrt{ }$ \\
\hline Enterococcus lactis & & $\sqrt{ }$ & $\sqrt{ }$ \\
\hline \multicolumn{4}{|l|}{ Antibiotic } \\
\hline Streptomycetes sp. & & $\sqrt{ }$ & $\sqrt{ }$ \\
\hline Total bacterial count $\left(\mathrm{CFU} \mathrm{mL} \mathrm{m}^{-1}\right)$ & $52.3 \times 10^{6}$ & $33.0 \times 10^{6}$ & $48.7 \times 10^{6}$ \\
\hline
\end{tabular}

The liquid compost of vegetable produced a significantly higher SGR than the liquid compost of fruit or that of a mix of fruit and vegetable.

Survival rates of monodon PL

The SRs in the treatments varied between 65 and $76 \%$ and did not differ from those of the controls (68\%), nor were they affected significantly by the treatments. These SRs are in the same range as those found by Ikhwanuddin et al. (2014) for T. catappa leaf litter leachates, by Nga et al. (2006) for R. apiculata leaf litter leachates, and by Rejeki et al. (2019) for minced and leaf litter leachates of both R. apiculata and A. marina.

Although non-significant, the SR in the mixed vegetable-fruit compost treatment was lower than those of the other treatments as well as the controls. The lower SR in treatments containing both vegetable and fruit may be attributable to harmful blooms of Peridinium sp. dinoflagellates (Keawtawee et al. 2012). Several authors (Hallegraeff 1993; Alonso and Osuna 2003; Songsangjinda et al. 2006) have reported that dinoflagellates significantly decrease yields of black tiger shrimp farms, and Yan et al. (2002) estimated that fish kills in Daya Bay, Guangdong, China, were caused by, among other species, Peridinium quinquecorne. The vegetable compost did not contain Peridinium sp., but Ceratium sp., which was reclassified as a Tripos sp. (Gómez 2013) and is not considered toxic (Ayada et al. 2018).

Effects of mangrove leaves and crushing

Chopping A. marina leaves significantly improved the SGR of shrimp by approximately 0.4 points compared with that of the whole leaves, both of which were dosed at $0.125 \mathrm{~g} \mathrm{~L}^{-1}$. This result aligns with that of Ikhwanuddin et al. (2014), who found higher growth rates of post-larva P. monodon in treatments of leachate compared with whole-leaf litter of T. catappa. Rejeki et al. (2019) observed superior shrimp growth in treatments of minced leaves and leaf leachate compared with whole leaves of $R$. apiculata and A. marina, all dosed at $0.125 \mathrm{~g} \mathrm{~L}^{-1}$. These findings suggest that chopping or crushing mangrove leaves makes the nutrients from this litter more readily available for conversion by bacteria and fungi and subsequently in nitrogen-rich detritus, giving the leachates a higher nutritional value. 
Our protocol did not include a treatment with mangrove leaves only; our study, therefore, cannot confirm whether adding whole leaves had a positive effect. However, Nga et al. (2006) found that moderate amounts (2.5-5 $\mathrm{g} \mathrm{L}^{-1}$ ) of leaves of $R$. apiculata positively favored shrimp growth.

Difference in the effect of the three composts

Although the farm-made liquid compost in this study contained fewer nutrients than the commercial alternatives, all three composts were associated with the increased growth of $P$. monodon juveniles. The standard of the Indonesian Agriculture Minister Regulation (2013) is probably the standard requirement for commercial liquid compost. The best growth was obtained from liquid compost with vegetable $\left(2.3\right.$ and $2.7 \%$ day $\left.^{-1}\right)$, followed by compost with fruit and mixed compost $\left(1.7-2.2 \%\right.$ day $\left.^{-1}\right)$, in which growth was at least $0.2 \%$ day $^{-1}$ higher than that of the control.

The liquid compost was made from wastes of vegetable and fruit by anaerobic fermentation. Yeast used to ferment cassava and added to start the fermentation process consisted of a combination of Amylomyces rouxii, Rhizopus oryzae, Endomycopsis burtonii, Mucor sp., Candida utilis, Saccharomycopsis fibuligera, Saccharomyces cerevisiae, and three lactic acid bacteria: Pediococcus pentosaceus, Lactobacillus plantarum, and Lactobacillus fermentum (Gandjar 2003). Although the yeast may have the same dosage, $5 \mathrm{~g}$ each liquid compost, the diversity and abundance of microbes during composting vary based on composting materials, nutritional supplements (Chandna et al. 2013), and duration of composting (Franke-Whittle et al. 2014). The present study confirmed this variation: Cellulomonas sp. were found in the vegetable and mixed compost, while Streptomycetes sp. were found in both the fruit and mixed compost, and Streptococcus sp. and B. thuringiensis were found only in the fruit compost.

The total bacterial count of the compost made from vegetable waste was higher $\left(52 \times 10^{6}\right)$ than that from fruit-based compost $\left(22 \times 10^{6}\right)$; this count was intermediate for the compost from mixed vegetable and fruit waste $\left(49 \times 10^{6}\right)$. All types of microorganisms that developed have positive characteristics. Enterococcus faecium has probiotic properties because of its ability to modulate the immune system of the host and thus improve responses against pathogens (Khalkhali and Mojgani 2017). Streptomycetes sp. secrete enzymes toxic to pests and diseases (de Lima Procópio et al. 2012). Streptomyceae are transitional organisms between bacteria and fungi that transform amino acids and similar substances produced by photosynthetic bacteria into antibiotics to control pathogens.

Of the three types of liquid compost, vegetable compost contained the highest levels of $\mathrm{N}, \mathrm{P}$, and $\mathrm{K}$. The high levels of $\mathrm{P}$ can be explained by the presence of two types of P-solubilizing bacteria (B. cereus and Microbacterium sp.) in the liquid compost with vegetable, while the fruit compost contained $B$. cereus and $B$. thuringiensis. Widawati and Suliasih (2006) stated that Bacillus sp. are P-solubilizing bacteria with the ability to dissolve $\mathrm{P}$ elements bound to other elements (e.g., $\mathrm{Fe}, \mathrm{Al}, \mathrm{Ca}$, and $\mathrm{Mg}$ ), while the Microbacterium strain solubilizes inorganic P to organic P (Zhu et al. 2011; Rivas et al. 2004); both make inorganic P more available. The higher content of $\mathrm{P}$ in the liquid compost with vegetable provided more nutrients because of the greater diversity of P-solubilizing bacteria in this treatment. N-fixing bacteria, such as Clostridium sp., capture $\mathrm{N}$ from the soil, water, and air to degrade organic material, making this $\mathrm{N}$ available as nitrate for use by plants. All three composts have Clostridium sp., but the total bacterial count in the vegetable compost was higher than that in the fruit compost, and we can assume that this contributed to the higher $\mathrm{P}$ and $\mathrm{N}$ contents.

Phytoplanktons are the major dietary component for juvenile penaeid shrimp in tidal mangrove creeks in peninsular Malaysia, next to benthic microalgae (Newell et al. 1995), and in the Philippines, next to epiphytic microalgae (Primavera 1993). Hena and Hishamuddin (2012) found that the foregut of post-larva P. monodon contained mostly detritus (as unidentified debris), followed by phytoplankton (mainly diatoms) and copepods. The majority of the plankton found in the three composts are Bacillariophyceae, which are diatoms. We can assume that the superior shrimp growth on the vegetable-based liquid compost was indirectly due to the higher availability of $\mathrm{N}$ and $\mathrm{P}$, both of which enhance the availability of plankton. 


\section{Conclusion}

Liquid compost made from vegetable was associated with the best growth rates of $P$. monodon juveniles. Shrimp survival was the same $(65-76 \%)$ for all treatments and the controls. However, shrimp growth was slightly lower with a liquid compost of fruit and the mixed compost, although it saw better growth than the controls. The lower specific growth rate with the fruit compost (2.0 vs. 2.5) may be a result of the presence of dinoflagellates in the mixture. Chopping or crushing A. marina leaf litter accelerated the absorption of nutrients from the leaves. Adding $0.125 \mathrm{~g} \mathrm{~L}^{-1}$ of chopped or whole mangrove leaf litter to the tank water improved shrimp growth.

Acknowledgements We heartily appreciate the Faculty of Fisheries and Marine Sciences, University of Diponegoro, for funding this research through NON-APBN Research Grant Funding Source No. 2300/UN.7.3.10/LT/2017 and NWO-WOTRO (Grant No. W 08.260.303). We acknowledge the PASMI project provision of the water quality equipment and cultivation facilities we used in this study. Thanks also to all our colleagues who assisted us in conducting this research until its completion.

Open Access This article is distributed under the terms of the Creative Commons Attribution 4.0 International License (http:// creativecommons.org/licenses/by/4.0/), which permits unrestricted use, distribution, and reproduction in any medium, provided you give appropriate credit to the original author(s) and the source, provide a link to the Creative Commons license, and indicate if changes were made.

\section{References}

Alonso RR, Osuna PF (2003) Nutrients, phytoplankton harmful algal blooms in shrimp ponds: a review with special reference to the situation in the Gulf of California. Aquaculture 219:317-336. https://doi.org/10.1016/S0044-8486(02)00509-4

Ayada M, Amira AB, Retima A (2018) Distribution of the Tripos species (dinoflagellata) from Annaba Bay (Southwestern Mediterranean sea). J Biodivers Environ Sci 12(2):40-50

Brown B, Fadillah R (2013) Fish farmer Field school: towards healthier milkfish/shrimp polyculture fish farmer empowerment in South Sulawesi. Aquac Asia 18(2):12-19

Busacker GP, Adelman TR, Goolish EM (1990) Growth. In: Schreck CB, Moyle PB (eds) Methods for fish biology. American Fisheries Society Bethesda Maryl, Bethesda, pp 363-377

Camilleri J (1989) Leaf choice by crustaceans in a mangrove forest in Queensland. Mar Biol 102(4):453-459

Chanda A, Akhand A, Manna S, Das S, Mukhopadhyay A, Das I, Hara S, Choudhury SB, Rao VK, Dadhwal VK (2016) Mangrove associates versus true mangroves: a comparative analysis of leaf litter decomposition in Sundarban. Wetl Ecol Manag 24(3):293-315. https://doi.org/10.1007/s11273-015-9456-9

Chandna P, Nain L, Singh S, Kuhad RC (2013) Assessment of bacterial diversity during composting of agricultural by products. BMC Microbiol 13:99

Cowan ST (2003) Cowan and steel's manual for identification of medical bacteria, 3rd edn. Cambridge University Press, Cambridge

de Lima Procópio RE, da Silva IR, Martins MK, de Azevedo JL, de Araújo JM (2012) Antibiotics produced by Streptomyces. Braz J Infect Dis 16(5):466-471. https://doi.org/10.1016/jbjid201208014

Franke-Whittle IH, Confalonieri A, Insam I, Schlegelmilch M, Körner I (2014) Changes in the microbial communities during cocomposting of digestants. Waste Manag J 34:632-641. https://doi.org/10.1016/jwasman201312009

Gandjar I (2003) Tapai from Cassava Cereals Paper presented at the First International Symposium Workshop on Insight to the World of Indigenous Fermented Foods for Technology Development Food Safety, Kasetsart University, August 13-17, 2003

Gómez F (2013) Reinstatement of the Dinoflagellate genus Tripos to replace Neoceratium, marine species of ceratium (Dinophyceae, Alveolata). Cicimar Oceánides 28(1):1-22

Hallegraeff GM (1993) A review of harmful algal blooms their apparent global increase. Phycologia 32:79-99. https://doi.org/10. 2216/i0031-8884-32-2-79.1

Hena MKA, Hishamuddin O (2012) Food selection preference of different ages and sizes of black tiger shrimp, Penaeus monodon Fabricius, in tropical aquaculture ponds in Malaysia. Afr J Biotechnol 11(22):6153-6159

Ikhwanuddin M, Moh JH, Hidayah M, Noor-Hidayati AB, Aina-Lyana NM, Juneta ASN (2014) Effect of Indian almond, Terminalia catappa leaves water extract on the survival rate growth performance of black tiger shrimp, Penaeus monodon post larvae. AACL Bioflux 7(2):85-93

Indonesian ministry of agriculture Republic of Indonesia (2013) Organic agriculture system. Number 64/Permentan/OT.140/5/ 2013

Keawtawee T, Fukami K, Songsangjinda P, Muangyao P (2012) Nutrient, phytoplankton harmful algal blooms in the shrimp culture ponds in Thailand. Kuroshio Sci 5(2):129-136

Khalkhali S, Mojgani N (2017) Enterococcus faecium; a suitable probiotic cidate for modulation of immune responses against pathogens. Int J Basic Sci Med 2(2):77-82. https://doi.org/10.15171/ijbsm.2017.15

Newell RIE, Marshall N, Sasekumar A, Chong VC (1995) Relative importance of benthic microalgae, phytoplankton, mangroves as sources of nutrition for penaeid prawns other coastal invertebrates from Malaysia. Mar Biol 123(3):595-606 
Nga BT, Roijackers R, Nghia TT, Ut VN, Scheffer M (2006) Effects of decomposing Rhizophora apiculata leaves on larvae of the shrimp Penaeus monodon. Aquac Int 14(5):467-477. https://doi.org/10.1007/s10499-006-9049-y

Niu J, Chen X, Zhang Y, Tian L, Lin H, Wang J, Wang Y (2016) The effect of different feeding rates on growth, feed efficiency and immunity of juvenile Penaeus monodon. Aquac Int 24(1):101-114. https://doi.org/10.1007/s10499-015-9911-x

Primavera JH (1993) A critical review of shrimp pond culture in the Philippines. Rev Fish Sci 1(2):151-201. https://doi.org/10. $1080 / 10641269309388539$

Primavera JH (2000) Integrated mangrove-aquaculture systems in Asia. In: Integrated coastal zone management, Autumn Edition. pp121-130. http://hdl.handle.net/10862/711

Reijntjes C, Haverkort B, Waters-Bayer A (1992) Farming for the future: an introduction to low-external-input sustainable agriculture. Macmillan, London

Rejeki S, Middeljans M, Widowati LL, Ariyati RW, Bosma RH (2019) The effects of decomposing mangrove leaf litter its tannins on the water quality, growth survival of tiger prawn (Penaeus monodon) post-larvae. Biodiversitas J 20(9):2750-2757. https://doi.org/10.13057/biodiv/d200941

Rivas R, Trujillo ME, Sánchez M, Mateos PF, Martínez-Molina E, Velázquez E (2004) Microbacterium ulmi sp. nov, a xylanolytic, phosphate-solubilizing bacterium isolated from sawdust of Ulmus nigra. Int J Syst Evol Microbiol 54:513-517. https://doi.org/10.1099/ijs.0.02724-0

Robertson AI (1988) Decomposition of mangrove leaf litter in tropical Australia. J Exp Mar Biol Ecol 116(3):235-247. https:// doi.org/10.1016/0022-0981(88)90029-9

Songsangjinda P, Yamamoto T, Fukami K, Kaewtawee T (2006) Importance of controlling community structure of living organisms in intensive shrimp culture ponds. Coast Mar Sci 30(1):91-99

Steinke TD, Barnabas AD, Somaru R (1990) Structural changes associated microbial activity accompanying decomposition of mangrove leaves in Mgeni Estuary. S Afr J Bot 56(1):39-48. https://doi.org/10.1016/S0254-6299(16)31109-7

USDA (2015). Standard operating policy/procedure: standard bacterial plate count. United States Department of Agriculture. Centre for Veterinary Biologics. Ames IA. BBSOP0019.04. pp 1-16

Widawati S, Suliasih (2006) Populasi Bakteri Pelarut Fosfat (BPF) di Cikaniki, Gunung Botol, dan Ciptarasa, serta Kemampuannya Melarutkan P Terikat di Media Pikovskaya Padat. Biodiversitas 7(2):109-113. https://doi.org/10.13057/ biodiv/d070203

Yan T, Ming-Jiang Z, Jing-Zhong Z (2002) A national report on harmful algal blooms in China. In: Taylor FJR, Trainer VL (eds) Harmful algal blooms in the PICES region of the North Pacific. PICES Scientific Report No. 23. North Pacific Marine Science Organization, Sidney, BC, Canada. pp. 119-128

Zhu F, Qu L, Hong X, Sun X (2011) Isolation characterization of a phosphate solubilising halophytic bacterium Kushneria sp. YCWA18 from Daqiao Saltern on the coast of yellow sea of China. Evid Based Complement Alternat Med 2011:615032. https://doi.org/10.1155/2011/615032

\section{Publisher's Note}

Springer Nature remains neutral with regard to jurisdictional claims in published maps and institutional affiliations. 